\title{
Minnen av olika material och olika tillvägagångssätt
}

\author{
Slöjd på fritidshemmet
}

\author{
Marcus Samuelsson
}

\begin{abstract}
Denna essä är en fallstudie som riktar uppmärksamheten mot en ung vuxen, Erik, och hans erfarenheter, minnen, berättelse och föremål från det som kallades för slöjd i olika material på ett fritidshem. Samtidigt är det en didaktisk studie då den $i$ korthet också berör hur blivande lärare i slöjd tolkar barns artefakter. Eriks berättelser om föremålen som gjorts i olika tekniker och olika material med mer eller mindre stöd av vuxna ger en bild av det som kallades slöjd på fritidshemmet. Essän bidrar för det första, utifrån samtalen med Erik om hans artefakter, med insikter om hur materiella förutsättningar och didaktisk inramning påverkar både vad som görs och hur det görs. Den bidrar för det andra, utifrån samtal med blivande lärare $i$ slöjd, också med insikter om hur vuxna riskerar att missuppfatta barns artefakter utifrån föreställningar om en sammanhållen gestaltning bortom materiella förutsättningar och didaktisk inramning.
\end{abstract}

\section{Inledning}

Vars och ens minnen av åren i skolan och skolslöjden kan härledas till olika saker. Minnen är å ena sidan egna och på så sätt unika, men de är, å andra sidan, också bitar av något som delas med andra. Minnen kan vara officiella, något samhället lärt oss, sina medborgare att komma ihåg och förhålla sig till, som Huss, Manns och Ruin beskriver det. De kan också vara inofficiella, som egna subjektiva hågkomster, likt dem denna essä kommer att handla om. I bästa fall är minnena sprungna ur stunder av njutning, närvaro och klarsyn, eller som Sigge Eklund (2020) benämner det - stunder av lågintensiv lycka. Det är dock inte alltid så. I en del fall, som i mitt eget, kan skolminnen också få en att fundera på det som man varit en del av. Ett konkret sådant minne är hur jag och mina tre bröder i skolans trä- och metallslöjd fick tillverka skohorn i teak. Teak är ett träslag som i bearbetad form inte lämpar sig för att hänga bredvid ett varmt element, varför vi i vårt barndomshem hade fyra spruckna, tämligen obrukbara skohorn. Detta är något vi bröder senare uppmärksammats på av vår mor, som också sparat de fyra spruckna skohornen. Och på detta sätt kan det vara. 
Berättelser om slöjd och skolan som vi vuxna får del av, i officiella eller inofficiella sammanhang, handlar inte sällan om lärare, elever, undervisningen eller resultatet av det någon lärt sig eller inte lärt sig i skolan. Berättelserna handlar när det gäller slöjd också om artefakterna, själva föremålen som tillverkats och hur arbetet att tillverka dem gått till. Att få del av någons minnen, eller att få möjlighet att minnas tillsammans med någon är en källa till kunskap som kan öppna dörrar till egna minnen. Att minnas tillsammans med någon ger inblickar och ökar förståelsen för det som varit och kanske alltjämt är väsentligt för någon annan, och därmed också kan innehålla något väsentligt även för oss själva.

Samtidigt som vi delar minnen med andra behöver vi också komma ihåg hur minnet fungerar. Minnesmästaren Jonas von Essen som våren 2020 gästade TVprogrammet Smartare än en femteklassare delade, förutom att kunna svaren på samtliga frågor, också med sig av sina erfarenheter och tekniker för att minnas. Han bjöd på minnesvärda sekvenser när han gick in i sitt minnespalats och därefter återgav hur han associativt och systematiskt letat sig fram till svar på de ställda frågorna. Hans sätt att resonera påminner om hur Kajsa Borg (2001) skrivit om minne. Hon poängterar att minnen innehåller ordnad information till följd av tidigare handlingar. Hon framhåller också om att vi kan använda minnen till stöd för att predicera framtiden och inte minst att vi minns det vi behöver minnas. I minnesmästarens fall för att klara uppgiften, svara på frågorna. Att minnas är ett slags skapande blir också tydligt vid läsning av Päivi Marjanen, Eila Lindfors och Sirpa Ketola (2018). De påvisar att olika faktorer påverkar förmågan att minnas och att dela med sig av minnen från det förgångna. De understryker att funktionen är en aktiv handling och att minnen tenderar att förändras med livet. De sätter också ord på det von Essen visade prov på när han letade efter svar på den sista frågan i TV-programmet - Vilket är samlingsnamnet för månarna Callisto, Ganymedes, Europa och Io som kretsar runt Jupiter? Minnesmästaren tänkte sig tillbaka till platser och situationer. Han gick på både rymdpromenader och historiepromenader och tog tittarna med sig till ett kvarter i Skövde som ett sätt att hitta svaret på frågan om samlingsnamnet Galileiska månarna. Lyckan som han, femteklassarna, programledaren och publiken gav uttryck för när svaret var rätt bekräftar Micael Dahlens (2020) tes om vikten av att minnas för att må bra och att återupplevelser gör det möjligt att uppleva sådant vi inte tänkte på när det pågick.

I det sammanhanget är denna text ett bidrag till att belysa minnen av slöjd. Uppmärksamheten riktas mot en ung vuxen, Erik, och hans erfarenheter av det som kallades för slöjd i olika material på ett fritidshem.

\section{Metodologi}

Essän är metodologiskt en fallstudie, och utgår från ett fall, Eriks minnen och berättelse. Essän är samtidigt ett bidrag till didaktiska studier på så sätt att den 
illustrerar hur någons artefakter som i detta fall vuxna pedagoger vid ett fritidshem talar om som slöjd, kan användas för att problematisera föreställningar om barns slöjdande i olika delar av skolans verksamhet. Essän är utöver ovanstående också ett försök, som essäer alltid är att läsaren bjuds in till att förstå och tolka den slöjd som bedrevs på ett fritidshem utifrån artefakter och en ung vuxens minnesbilder. Denna essä uppehåller sig därmed inte som essäer vanligtvis gör vid författarens egna erfarenheter, däremot innehåller den dock mina egna tankar såsom essäer ofta gör. Formen är personlig utan att det konkreta för den skull tappas bort (Alsterdal, 2014). Essän handlar om Eriks erfarenheter som han minns dem. Hans erfarenheter delas till läsaren på ett tydligt, läsarvänligt och personligt sätt (Olsén, 2003). På så sätt strävar essän, genom att sätta ämnet i fokus efter att beröra (Alsterdal, 2014) oss med intresse för barns möte med slöjd. När vi talar om att beröra så är det värt att nämna för den ovana läsaren att svenska pedagoger eller lärare inte erbjuds utbildning för att undervisa i slöjd på fritidshemmet. Det finns inte heller några nationella styrdokument som ger stöd för en sådan verksamhet. Den slöjd som Erik erfor och minns från sitt år på fritidshemmet när han var sex år gammal påminner å ena sidan om det många andra gjort och minns från sin tid på fritidshem, men den är å andra sidan också något annat än den slöjd som de senare tar del av i grundskolan.

\section{Skolminnen}

Liksom forskare intresserar sig också författare för minnen. Flera är de som använt minnesbilder av skolan och lärare i sina böcker. Oavsett om de är fiktiva verk som Augustprisbelönade Underdog av Torbjörn Flygt (2001) eller biografiska verk som Minnena ser dig av Nobelpristagaren i litteratur Tomas Tranströmer (1993). I sin bok tecknar Flygt ett porträtt av en grovhuggen sadist till lärare och hans velourklädde lärarkandidat medan Tranströmer skildrar minnen av färgstarka lärare som skapade högspänning genom sitt sätt att leda undervisning.

Minnen har också intresserat myndigheter, bland annat för att locka människor till högre utbildningar. Skolverkets digitala satsning kallad För det vidare (fordetvidare.se) är ett sådant exempel. Här visas tio filmer med kända svenskar som berättar om och söker upp någon av sina gamla lärare som haft betydelse för dem. Målet med satsningen var att få flera att utbilda sig till lärare. Kändisarnas beskrivningar analyserades och kategoriserades av mig, Joakim Samuelsson och Lars Kåreklint (2014). Vi kunde konstatera att kändisarna mindes lärarnas egenskaper - entusiastisk, god förebild och någon som väckte respekt, tillit och trygghet. De mindes också undervisningens karaktär som fängslande, lustfylld, relevant, och som att den gav vidgade vyer. Vi fann vidare att de mindes lärare som haft goda relationer med sina elever, haft tydliga idéer 
för sin undervisning och tagit ansvar för en angelägen verksamhet undervisning. Vi drog slutsatsen att det finns ett stort värde i att lyfta fram positiva minnesbilder av människors tid i skolan som kontrast till de annars vanligare förekommande skildringarna av brister i skolan eller lärares tillkortakommanden.

\section{Slöjdminnen}

Att före detta elever investerat starkt känslomässigt i arbetet i skolslöjden märks i Kajsa Borgs tidigare nämnda text. En del av dem hon träffat mindes slöjden med glädje och stolthet medan andra mindes arbetet som monotont och obefogat. De mindes lärare utifrån deras egenskaper och deras förmåga att bedriva begriplig undervisning. Detta gäller inte bara i Sverige vilket visas i texten som Päivi Marjanen, Eila Lindfors och Sirpa Ketola har skrivit om minnen från skolslöjden i Finland, som mestadels beskrivs som positiva. Men det fanns också de som upplevt sina lärare som hemskt griniga.

Fler än forskare intresserar sig för och gör poänger av minnen av slöjden. En svensk ståuppkomiker som verkat över lång tid gjorde ett nummer av sina erfarenheter i skolslöjden. Delar av ett framträdande publicerades så småningom på Facebook. Om det var kändisfaktorn, igenkänningsfaktorn eller humorfaktorn eller en kombination av dem som fick så många att gilla inlägget med tummen upp och bidra med kommentar och dela inlägget kan och bör vi fundera och reflektera över.

$20 \mathrm{maj} 2012 \cdot 6$

Văr träslöjdmagister hette Folke. Han var aldrig nöjd med mina smörknivar: "Nja, du făr nog ta ett tag till med ettans sandpapper!"

Jag höll på i fyra månader med en satans smörkniv som man kan köpa på Konsum för fem jāvla spänn!

Om jag nån gång träffar Folke igen ska jag köra upp en smörkniv i röven på honom. Och då vet jag vad jag kommer att säga...

630

96 kommentarer 28 delningar

Figur 1. Skärmdump från Facebook, juli, 2020.

Kanske kan komikerns inlägg tolkas som att det företräder det kränkta, oförstående och sårande barnet, att det är en spark underifrån riktad uppåt och/eller ett uppror mot en auktoritet. Eller är det helt enkelt bara ett försök att vara roligt, underhållande och skämtsam på en lärares bekostnad. Oavsett vilket så vet vi av historien att det är tacksamt att driva med något som många känner igen och kan associera till utifrån deras personliga subjektiva minnen. Personliga minnen eller fallbeskrivningar ska därmed inte underskattas. De kan 
användas för att belysa händelser och skeenden i specifika verksamheter. Men när det görs av forskare för vi samtidigt ett resonemang om fallets möjligheter och begränsningar.

Att dela erfarenheter och minnen med varandra är en egenskap som ligger till grund för hållbara gemenskaper. Delandet sker inte sällan i form av artefakter, berättelser och exempel. Människor en art som utvecklats länge och väl tack vare förmågan att överföra erfarenheter $\mathrm{i}$ form av historier enligt Michael Tomasello (2011). Historier har, liksom stå-upp komik, alltid byggts upp kring exempel. På så sätt tillskrivs exemplen makt. Vi behöver ändå komma ihåg att exempel alltid är exempel på något, och att det alltid finns något allmänt i varje exempel som Tore Nordenstam (2005) uttrycker det. Nordenstam fortsätter resonera om ett samband mellan begrepp och exempel och han illustrerar detta med ett antal begrepp. Begreppet normalitetsvillkor kan förstås som en överenskommelse om förhållandet mellan saker och ting som råder i normala fall. Att normala fall, som ett uttryck för normalitet, kan problematiseras illustreras av Jan-Håkan Hanssons och Tommy Svensson (1998) med deras uppdelning av normal som naturenlig, vanlig eller normenlig. Men åter till Nordenstam som resonerar vidare om begrepp med särskild anknytning till specifika personer eller omständigheter och framhåller att det allmännas funktion i ett enskilt fall fungerar som en riktningsanvisning, en styrning av uppmärksamheten i en eller annan riktning. Ett kompletterande sätt att resonera om exempel skriver Staffan Larsson (2009) om i en artikel generaliseringar i kvalitativa studier. Han lyfter bland annat fram tre generaliseringskriterier. Larssons första kriterium handlar om att maximera variationen $\mathrm{i}$ det som studeras, vilket är svårt att göra i ett fall. Hans andra kriterium fokuserar på generaliseringar utifrån kontextlikhet som gör det möjligt att känna igen i upplevelser eller beskrivningar av en annan kontext. Larsson resonerar också om mönsterigenkänning som handlar om att beskrivningar hjälper oss att identifiera kvaliteter hos fenomen eller processer. Det är väsentlig att ha sådana resonemang $\mathrm{i}$ åtanke när man tar del av beskrivningen av en ung vuxens minnen från slöjd på ett fritidshem.

\section{Artefakter och erfarenheter}

Att artefakterna, föremålen eller sakerna som Erik kallar dem och som bildar utgångspunkt för denna essä, över huvud taget skulle finns kvar var inte givet. Det var resultatet av en vårdnadshavares samlande av det barnet hanterat och gjort i olika skolformer, och som liknar det sätt på vilket min mor sparat mina och mina bröders slöjdalster. Eriks teckningar, böcker, klassfoton liksom artefakter från olika slags slöjd fanns samlat i lådor. Detta är i sig inget unikt, det har förekommit tidigare, vilket bland annat Marléne Johansson (2008) skildrat. Att det förekommer än idag tar jag också för givet. Att samla saker är ett sätt för 
oss att göra det möjligt att komma ihåg. Artefakter liksom foton blir en tankestötta som hjälper oss att associera till platser, tidpunkter och personer.

Efter att jag sett artefakterna fick jag lust att tala med den unga vuxna, Erik, som hade gjort dem under ett år på fritidshemmet när han var sex år. Vi samtalade några gånger om hans minnen av sakerna och verksamheten på fritidshemmet. Ganska snart föddes en idé om hur det han gjort kunde komma till nytta i undervisning av blivande lärare i slöjd. Jag frågade och fick Eriks tillåtelse till att använda sakerna för det ändamålet. Hur det gjordes och hur det gick återkommer jag till, men först efter att jag beskrivit Eriks minnen av fritidshemmet och den slöjd som han fick del av där.

\section{Vardag på fritidshemmet}

Erik mindes året $\mathrm{i}$ fritidshemmet som roligt, mestadels utifrån det han gjorde med kompisarna, killarna och tjejerna på fritids. Han kom också ihåg skillnader mellan de strukturerade förmiddagarna i förskoleklassen med skolliknande verksamhet som läsning, räkning och skrivning som kontrasterades mot friare eftermiddagar där de också fick möjlighet att slöjda. När bokstäver presenterades på förmiddagarna lärde sig barnen en sång utifrån materialet Majas alfabetssånger. Erik mindes alfabetssångerna och associerade dem till sommarveckorna som han tillbringade hos sin farmor och farfar, där sångerna också sjöngs.

Tänker jag på D kommer jag fortfarande ihåg Daggkåpa. Genom sångerna fick man något mer än bokstäver, än bara en bokstav, också något att knyta ann till.

Erik kommer ihåg dagliga rutiner såväl som enstaka incidenter från den tiden. Vid ett tillfälle hade en kille tagit med sig en kniv till fritids som han visade när han klättrat högst upp i klätterställningen. Vid sidan av minnen av kompisar mindes Erik också att personalen varit snäll och hjälpsam.

Eftermiddagarna bestod av mycket lek, oftast utomhus. De stunderna mindes Erik som de bästa av allt på fritids. Han och hans kompisar fick då leka utan de vuxnas inblandning i något som "var som en egen värld". De fick bestämma egna lekar som "herren på täppan", "bollen i burken" och "kurragömma" på gården runt fritids. En gård som bestod av en asfalterad gång till och runt förskolan/fritidshemmet och ett intilliggande förråd omgärdat av en kuperad gräsmatta, en gräsbevuxen kulle, bärbuskar och en skogsdunge av lövträd. Bland träden i skogsdungen lekte och klättrade de tillsammans. Runt husen körde de på sparkcyklar. De fick också lov att plocka och äta av de vita vinbären och på höstarna samlades löv från träden till en stor lövhög som de fick hoppa i som Erik mindes det. 
Att leken tillsammans med kompisarna utomhus har skapat minnen hos Erik blir tydligt. Han ler medan han berättar och skrattar åt saker som han kommer på under vårt samtal.

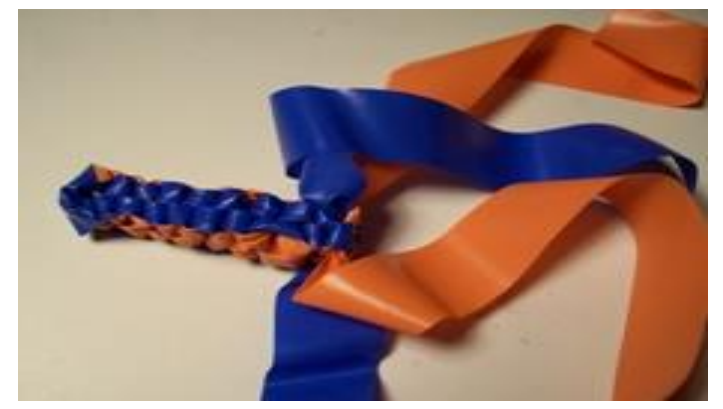

Figur 2. Plastband som Erik flätat med under tiden på fritidshemmet.

En sådan händelse, som han mindes extra väl, följer efter att jag visar flätan i blått och orange för honom. Han lyste upp och pratade en lång stund om flätan, som börjat som en motorisk aktivitet.

Det började som en rolig grej, någon gjorde en fläta med plastband. Någon började fläta och ganska snart tävlade killarna om vem som kunde få den längsta flätan. Då kom någon på att vi kunde ju sätta samman flätorna till en gemensam jättelång fläta. Det gavs oss ny motivation och vi flätade runt kullen och tillbaka igen tills banden tog slut. Alla var med och hjälptes åt, både killar och tjejer.

Erik tänkte att många av aktiviteterna som de gjorde nog handlade om motorisk träning. Det verkade vara viktigare att vara sysselsatt med handen och tanken "än att göra faktiska, användbara saker". Samtidigt var det så att de inte "bara skulle göra något, utan det skulle samtidigt vara något man hade tänkt på".

Vi skulle inte bara gå ut och slå i fem spikar i en träbit, utan vi skulle försöka göra någonting. Men det behövde inte fungera för att det skulle vara något bra liksom.

Erik återkom till att det skulle vara en tanke bakom och han berättade vid ett tillfälle:

Jag gjorde mina saker med en tanke bakom, jag satt inte bara och kladdade färg på ett papper, med lite grönt och lite blått.

Att göra saker, som motorisk träning innebar också en form av slöjd, i både hårda och mjuka material.

\section{Slöjd i hårda material}


Förrådet på skolgården hade flera dörrar, bakom en av dem fanns snickarboden. Det var ett litet rum med plats för två, tre barn åt gången. Erik minns att snickarboden hade bänkar, material och verktyg. Barnen, mestadels killarna, var ensamma därinne. Om de behövde hjälp att till exempel limma ihop vissa saker så kunde de be de vuxna att hjälpa till.

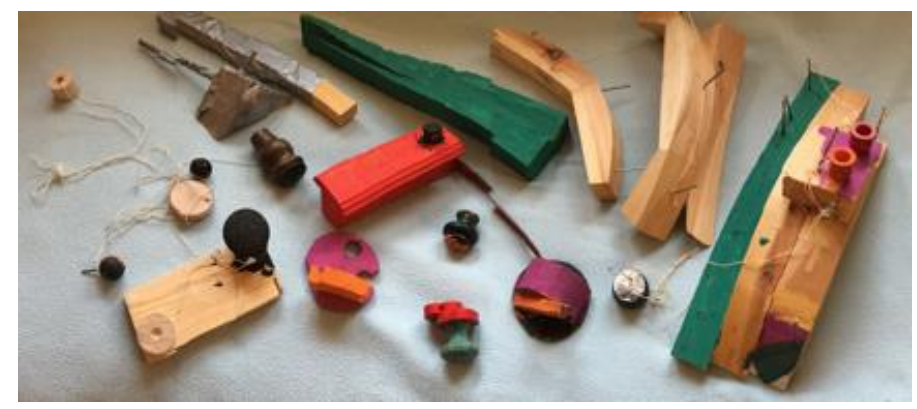

Figur 3. Samtliga artefakter i hårda material som Erik skapat på fritidshemmet.

När Erik får se de sparade sakerna han gjort i hårda material på fritids skrattar han till. Hans blick scannar av sakerna och han sorterar dem därefter i olika grupper med händerna. Det handlar om vilka material som använts, vad de använde sakerna till och när de är gjorda, berättar han.

Erik började berätta om artefakterna med snören som han gillade att arbeta med.

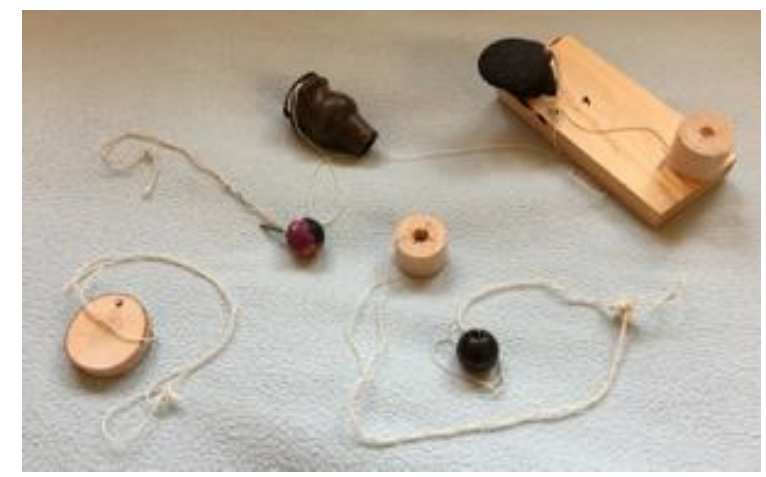

Figur 4. Artefakter med snören.

Träbitarna som knöts fast i snören fanns i några fall färdiga i snickarboden. Andra artefakter, som den sammansatta brädan och "medaljen" skapades av Erik. Han "trodde att en del av detta var gjort för att hänga i julgranen" och att "medaljen" påminde om de minnesbrickor som han fick på det idrottsläger som han som barn deltog i varje sommar och där han fortfarande deltar, fast nu som ledare. 


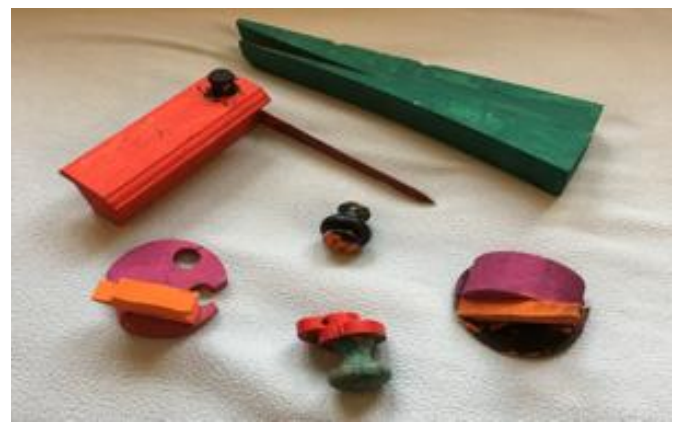

Figur 5. Sammansatta och färgsatta artefakter.

Nästa grupp av artefakter som Erik pratade om är de sammansatta och målade sakerna. Erik kom ihåg att han "fick hjälp av någon av pedagogerna att limma ihop bitarna". Dessa artefakter associerade han till två saker. Först till den då populära serien Pokémon, som gick på TV och fanns som spelkort när Erik gick på fritids. En del av artefakterna kunde vara olika Pokémons. Han associerade dem även till en fritidsaktivitet, "detta hade nog med vår cykling att göra, tror det är flyg eller gupp" berättade Erik. Han och hans kompisar körde cykelcross efter fritids på en bana med sådana "flyg" som de byggt själva.

Dessa saker kunde Erik tydligt koppla samman med något han ägnat sig åt och påverkats av. Det skiljde sig från andra saker som han inte på samma sätt kunde associera till någon aktivitet.

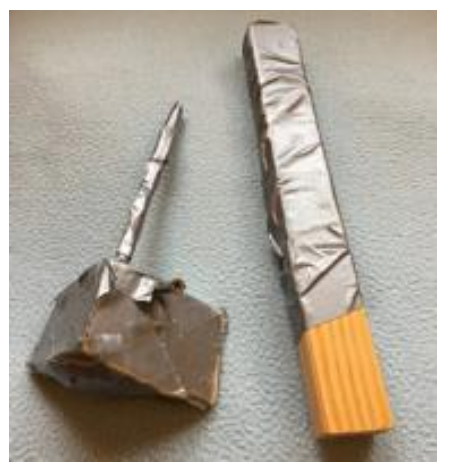

Figur 6. Slumpmässigt skapade artefakter med silvertejp.

Erik påpekar att en del artefakter kom till mer eller mindre av en slump, som de med silvertejp. 
Här hade vi fått tag i en rulle med tejp, som vi använde. Det ena är ett svärd och det andra är en walkie talkie.

Han mindes inte varifrån tejpen kom och inte heller hur dessa saker användes. Erik plockade istället fram några saker som verkade höra samman och berättade hur han gick tillväga "här testade jag mig fram, steg 1, steg 2 och steg 3.

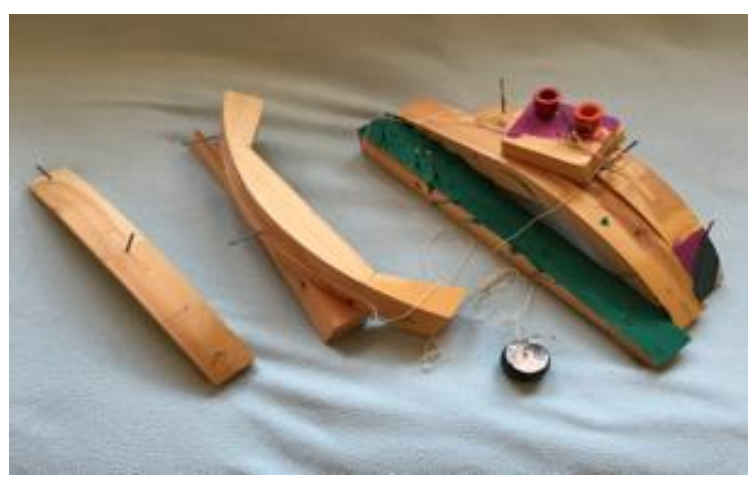

Figur 7. Prototyper till båtar.

Stegen speglade hans idé om att "vilja göra en finare båt". Erik stannade upp en stund och plockade fram den mest sammansatta båten. "Här syns det tydligt", han tystnade en stund och fortsatte sedan:

Jag har en bild av att jag det jag gjorde, hur det såg ut, jag hade en tanke, med staket och jämna avstånd mellan spikar hela vägen runt.

Han visade med ett finger på båten och säger "här ser man ju att jag har gjort den där staketliknande saken, det kan mycket väl ha varit första steget $\mathrm{i}$ båtbygget där jag testar vad jag skulle ha". Tillverkningen av båtar kopplade han samman med somrarna hos sin farmor och farfar och turerna de gjorde med en skärgårdsbåt "med skorsten, förarhytt, reling och så där". Den båten liknade de båtar han försökte bygga.

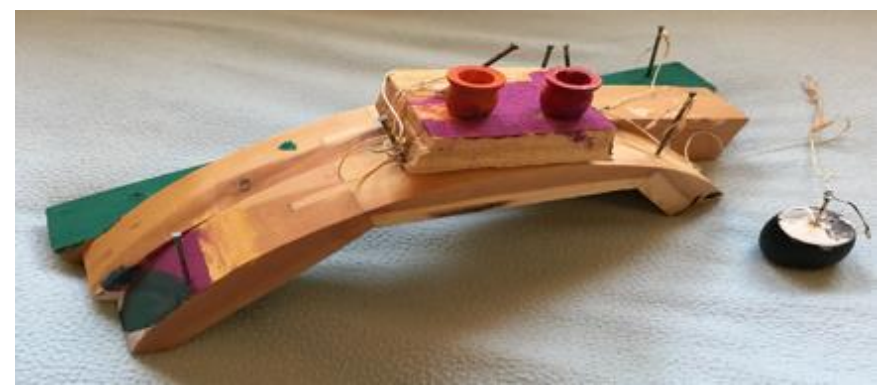

Figur 8. Eriks tolkning av skärgårdsbåt. 
Vad som gjordes i snickarboden påverkades också av kompisar och Erik mindes att "det lockade mest att vara med dem" därför att de "hjälptes åt $i$ snickarboden". Erik fick mig att förstå att gemenskapen i snickarboden var speciell, där "kunde man vara mest kreativ och skapa eget, för träet är ju som det är”.

Erik såg ännu en gång på sina saker, med huvudet lite på sned och ett varmt leende på läpparna. Sedan tittade han upp och bad mig visa "de andra sakerna", slöjdade i mjuka material.

\section{Slöjd i mjuka material}

De mjuka materialen slöjdade de med inomhus, på fritidshemmet som Erik minns det. Till skillnad mot slöjd i hårda material som mestadels gjordes utan vuxnas medverkan genomfördes slöjden i mjuka material alltid med någon pedagog närvarande. Erik berättade att pedagogen hjälpte till att plocka fram material från undanställda lådor och låsta skåp. De hjälpte också till med att trä på nålar eller sätta upp små vävar. Slöjd i mjuka material krävde pedagogernas närvaro. Erik minns hur han gillade att slöjda i pedagogers närvaro, kanske för att han gillade pedagogen och för att slöjden i mjuka material var annorlunda än slöjden i hårda material.

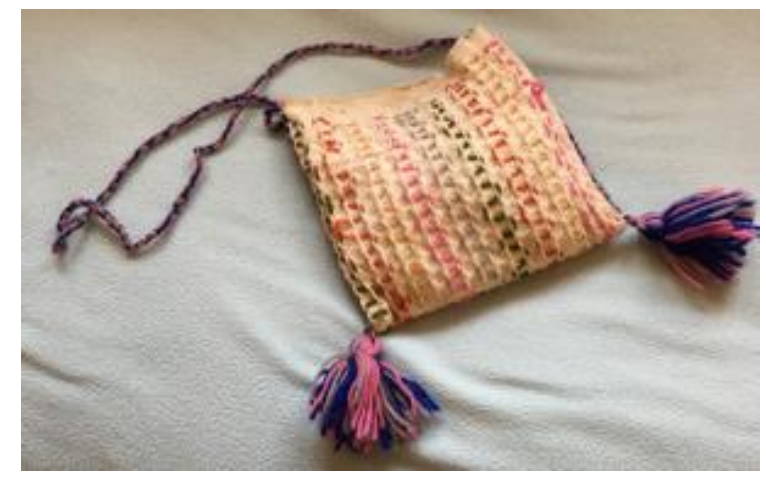

Figur 9. Slöjdpåsen med Eriks artefakter i mjuka material.

Erik skrattade till när jag visar hans slöjdpåse och säger spontant "den minns jag, wow, den minns jag, herregud vad häftigt". Han berättar att påsen var bland det första de gjorde för att de skulle ha en påse att ha sina grejer i. Arbetet med påsen var "skitkul, att liksom få göra en egen påse och välja färger och så där". Vi fick välja färger och skapa egna mönster, berättade Erik.

Jag ville nog ha många så färger som möjligt liksom. Vet inte varför jag valde specifika färger men mönstret vet jag inte varför egentligen. 
Erik plockade ut innehållet ur påsen och la det på bordet framför oss.

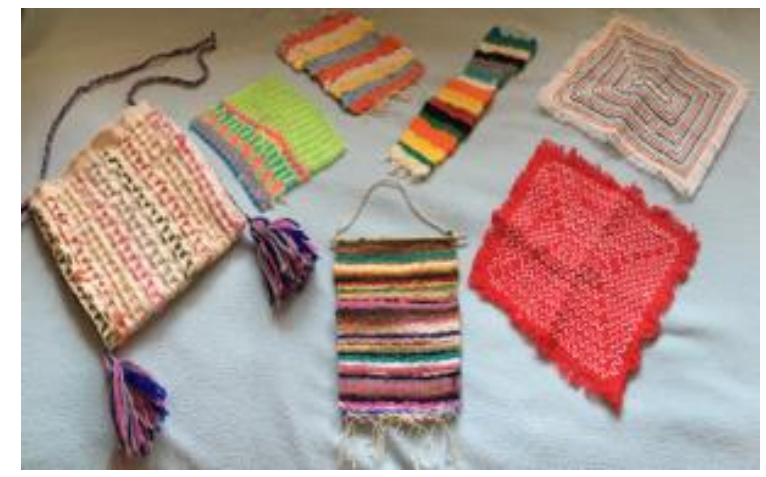

Figur 10. Samtliga artefakter i mjuka material som Erik skapat på fritidshemmet.

Han tittade på artefakterna, kände på dem och sa att han inte mindes så mycket, men att han "tyckte dom blev väldigt bra då och att han var väldigt stolt över sina grejer". Han sorterade upp sakerna i två högar, det vävda för sig och det broderade för sig.

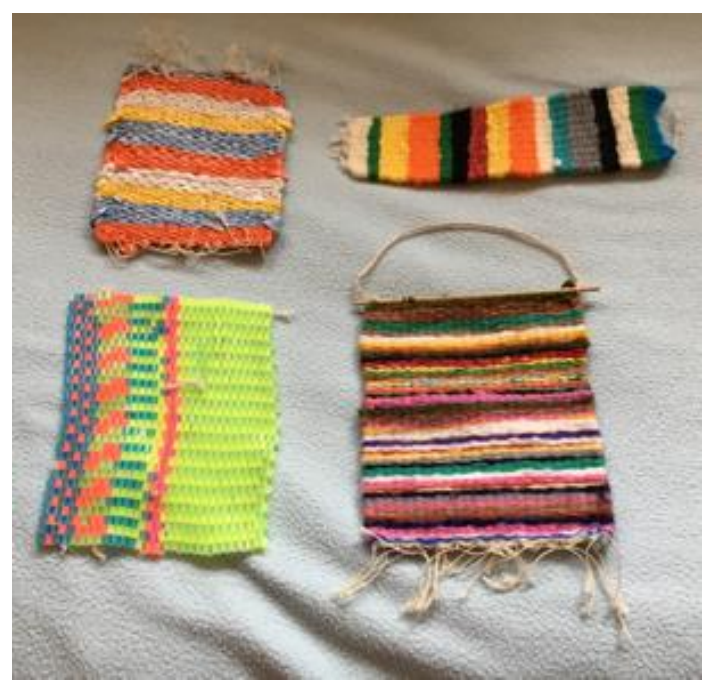

Figur 11. Eriks vävda artefakter.

Erik kom ihåg att de vävda sakerna gjordes i en viss ordning. Först gjordes "plastmattan, sedan pärlmattan, sedan smala mattan och till sist väggbonaden". Han berättade att det var någon där som hjälpte till när de behövde det. Erik log ännu en gång när han såg sina saker och mindes att han höll på länge med väggbonaden. 
Jag bytte färger och så, det är nästan alla olika färger. Det var ju kul att byta färg, kul att experimentera med vilka man tyckte om och så.

Erik konstaterade att en del färger återkommer ofta, som vitt, rosa och grönt. Han konstaterade också nöjt att det är hårt pressat och raka kanter. Erik menar att det var viktigt "med mycket färger och att göra noga".

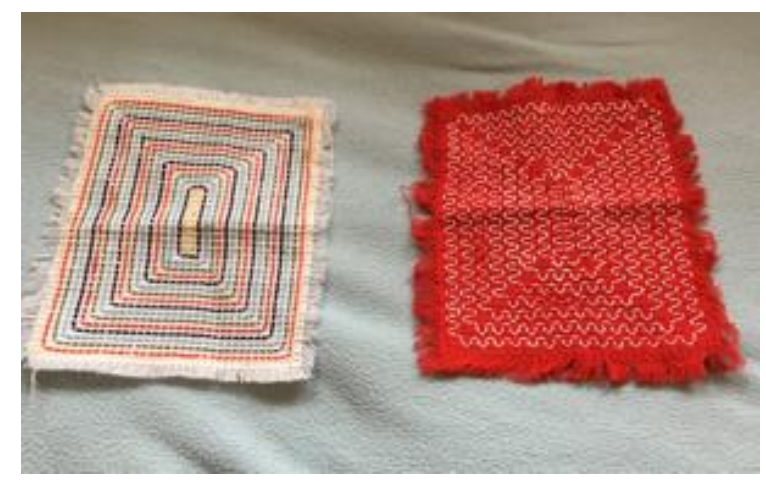

Figur 12. Eriks broderade dukar.

Erik plockar fram dukarna som han broderat. Han hade börjat med den vita och kunde byta färger och blanda hur han ville. Men färgbyten mitt $\mathrm{i}$ var inget för honom. Han minns att han tänkte mera som att det "fanns ett sätt att göra det på, och att han gillade det konceptet och att det fanns riktlinjer allt följa". Han skapade en ordning med sina färgval och höll sig sedan till den.

Erik berättade att slöjden i de mjuka materialen var ett skönt avbrott mot den andra verksamheten. Att han gillade den slöjden var inte så konstigt därför att han också "gillade ju att bygga med Lego. Han tänkte att den mjuka slöjden "var lite likadant, var sak på sin plats" med avseende på systematiken och att det fanns ett sätt att göra det på:

Du ska dra den under varje tråd eller maska, du ska dra varannan. Det ingav lite trygghet och lite kontroll.

Han berättar att gillade det mera strukturerade, och att han inte kunde improvisera jättemycket därför att "det fanns ändå en ram och ett sätt att göra det på”. Han tänkte högt:

Jag verkar ha varit metodisk. Inte tjuvat lite och hoppat över något steg ibland. Jag är förvånad över att jag inte tagit några genvägar som är direkt iögonfallande. 
Erik reflekterade över sakerna han gjort i de mjuka materialen.

Jag tror inte det var mitt eget beslut att testa och göra dukar och det här. Jag tror inte det var så att jag kände att jag behövde göra något, utan jag gillade att göra det här (Erik pekade på den vävda mattan av plastband) och jag hade nog nöjt mig med att variera färgen lite mer och så.

\section{Skapar skilda förutsättningar för slöjd olika minnen?}

Eriks erfarenheter och föremål som underlag för diskussion och lärdomar ger både begränsningar och möjligheter. De är exempel på något som gjorts i en institutionell verksamhet i början av 2000-talet med specifika förutsättningar under större eller minde närvaro av en pedagog utan specifik utbildning för att undervisa i slöjd. De kan också liknas vid motorisk träning i en verksamhet utan specifika mål för slöjd. Men de är samtidigt uttryck för en allmängiltighet, en universalism och har på så sätt en hög igenkänningsfaktor såsom Staffan Larsson (2009) skriver om. Vi är många som minns vad vi gjort som barn. Många av oss exponeras troligen också för vad andras barn gjort och fortfarande gör under sin tid på fritidshemmet. Varför det är på det viset kan vi fråga oss? Är det så svenska barn numera introduceras till att slöjda? Eller ska verksamheten istället beskrivas, utan att den skulle värderas, som motorisk träning $\mathrm{i}$ hårda och mjuka material? Kan att göra en "slöjdpåse" som Kajsa Borg (2008) resonerar om förstås som traderad kunskap? Fler frågor kan sannolikt formuleras.

Men, låt oss för en stund resonera om föremålen som Erik gjorde under sitt år på fritidshemmet. Föremålen i hårda material tolkar jag som explorativa och samtidigt reproducerade. De är gjorda av olika material, som sammanfogats och färgsatts för att skapa ett personligt uttryck associerade till händelser och personer utanför livet på fritids som Erik minns det. Föremålen som är gjorda i mjuka material tolkar jag som repetitiva och progressiva. De är skapade av olika material och färger som han använt för att skapa andra former av personligt uttryck. De är utan associationer till händelser eller personer utanför fritids enligt Erik. Han var under arbetet påverkad av materiella egenskaper, dem han umgicks med och plockade på olika sätt in sina sociokulturella referenser i en flera av sakerna. Samtidigt hade han inga minnen av motiven för val av färg och form hos andra delar av sina saker. En del av hans saker är expressiva och andra är återhållsamma. Det kan förstås handla om vad han minns och inte minns, och vilken funktion han adderar till för att försöka minnas. Det kan handla om att motiven för att slöjda förändrats över tid. Men det kan också handla om kontexten, en snickarbod med kompisar som Erik gillade att vara med och som han delade erfarenheter med både i och utanför fritidshemmet. I ett annat fall ett klassrum med en pedagog som han också gillade att vara med, men för övrigt inte mindes så mycket av. Det kan också handla om materialens dialektik som 
erbjudit Erik olika förutsättningar som han på olika sätt svarat upp emot, arbetat med, lärt sig av och skapat minnen och associationer till. Låt oss inte heller glömma bort att Eriks sätt att tala om sakerna och året på fritidshemmet fick honom att skina upp och intensivt börja berätta om något som varit värdefullt för honom. Detta något, det som Erik mindes som slöjd på fritidshemmet, har drag av en lågintensiv lycka såsom Sigge Eklund (2020) beskriver det.

För egen del fascineras jag av Eriks föremål, erfarenheter och hans minnen av slöjden på fritidshemmet. Därför återkommer jag nu, som tidigare utlovats, till att jag fătt låna föremålen till undervisning i didaktik för blivande lärare i slöjd som jag emellanåt haft möjlighet att genomföra. Lärarstudenterna som jag träffat fick, uppdelade i två grupper, till uppgift att tänka kring föremålen utifrån ett antal didaktiska frågor om legitimitet, selektion och kommunikation som Lars-Owe Dahlgren (1990) formulerat dem. Konkret fick de i uppgift att formulera svara på frågor som: Vem har skapat sakerna? Vilken ålder har slöjdaren? Vilken funktion har föremålen? Hur kan sakerna förstås? Vad kan artefakterna lära oss om fritt och/eller styrt slöjdande?

Lärarstudenterna tittade, kände, vände och vred på artefakterna i antingen mjuka eller hårda material under en begränsad tid och bytte sedan föremål med varandra. Efter ännu en stund med artefakterna i det andra materialet, presenterade de sina tolkningar för varandra och för mig följt av en diskussion om deras slutsatser, deras preliminära svar och vad de kommit fram till. I samtalen återkom studenterna till några saker värda att stanna upp inför: De menade till att börja med att sakerna var gjorda av två olika personer! Sakerna i hårda material av en kille och sakerna i mjuka material av en tjej! Argumenten för den slutsatsen var tillvägagångsättet och resultatet. De menade vidare att barnen, killen och tjejen, som skapat föremålen inte hade samma ålder! De hade svårt att beskriva vad sakerna $\mathrm{i}$ trä föreställde medan de enkelt kunde kategorisera vad de textila föremålen var för något. De kunde inte säga något om fritt eller styrt slöjdande utifrån föremålen. De kunde inte heller avhålla sig från att värdera föremålen utifrån hur de var gjorda, fast detta låg bortom uppgiften de hade fått att arbeta med.

Lärarstudenternas slutsatser är, utöver Eriks minnen relevanta att stanna upp vid, tänka över och lära sig något av då de utgör exempel på något, som Tore Nordenstam (2005) uttryckt det. Deras slutsatser säger något om föreställningar eller missuppfattningar som vi alla bär på. De säger också något om erfarenheter som färgar våra tolkningar och värderingar också om barns slöjdande i skolan, eller som i detta exempel på fritidshemmet. Föremålen såsom de är gjorda och färgsatta styrde lärarstudenternas uppmärksamhet i olika riktning. Föremålens uttryck matchade deras föreställningar om vad de menade var normalt, i 
betydelsen vanligt och normenlig såsom Jan-Håkan Hansson och Tommy Svenssons (1998) beskrivit det. Studenterna menade sig känna igen mönster som stämde överens med deras erfarenheter av och uppfattning om killar och tjejers slöjdande i hårda och mjuka material. Det kände däremot inte igen sig $\mathrm{i}$ att ett barns samlade produktion kunde innehålla en sådan bredd och variation av slarvigt - noggrant, fantasifullt - traditionellt, som de uttryckte det. Den erfarenheten förefaller värdefull att bära med sig som människa, som lärare i slöjd, som är ett skolämne, med två materiella inriktningar med samma kunskapskrav. Lärarstudenternas föreställningar om barn, slöjd, material, normalitet och kvalitet utmanades på så sätt av ett enda exempel.

Om och på vilket sätt dessa eller för den delen även andra lärarstudenters föreställningar om slöjd $i$ en institutionell kontext som skolan och fritidshemmet eventuellt skulle utmanats av flera exempel återstår att undersöka, undervisa om och rapportera om i en annan text. I väntan på det återvänder jag till denna text om Erik, som i mitt tycke står på sina egna ben. Jag hoppas texten gjort rättvisa åt Eriks minnen och erfarenheter av det som kallades för slöjd på fritidshemmet. Jag hoppas också texten gjort rättvisa åt de känslor av lycka som jag läste av i Eriks verbala och icke-verbala uttryck inför återseendet av sina artefakter. Det han gjort i slöjden på fritidshemmet gjorde honom alltjämt lycklig. Jag tror att Eriks föremål och berättelse kan utgöra en utgångspunkt, fylla en funktion och bli ett väsentligt bidrag till fortsatta diskussioner om materialens egenskaper och styrande funktion för barns slöjdande. Materialiteten, kamratskap, associationer till nära och fjärran erfarenheter var det som styrde hans slöjd i både mjuka och hårda material, som han mindes det, med ett varmt leende på läpparna och några överraskande skratt när föremål från ganska länge sedan återsågs igen.

Erik styrdes i mindre grad av de vuxna, pedagogerna, enligt hans egna kommentarer. För mig som mestadels ägnat min forskning åt studier av ledarskap i klassrummet, eller som jag hellre skulle kalla det, didaktiskt ledarskap och barns motstånd i skolan, är det överraskande och hoppfullt. Överraskande därför att många, numera vuxna, minns de lärare de haft omkring sig när de slöjdat och deras negativa eller positiva inflytande. Också därför att många barn framhåller att vuxna $\mathrm{i}$ skolan varit de näst viktigaste personerna $\mathrm{i}$ deras liv efter vårdnadshavarna. Hoppfullt därför att Eriks berättelse, hans minnen av artefakter och hans erfarenheter som präglats av en integritet som han fick möjlighet att bevara, utveckla och gestalta i sina föremål i mjuka och hårda material från slöjden i fritidshemmet. 


\section{Referenser}

Alsterdal, L. (2014). Essäskrivande som utforskande. I A. Burman (red.), Konst och lärande: Essäer om estetiska lärprocesser. Huddinge: Södertörns högskola.

Borg, K. (2001). Slöjdämnet, intryck, uttryck, avtryck. Linköping: Linköpings universitet. https://doi.org/10.3384/diss.diva-143165

Borg, K. (2008). Alla dessa påsar. Kritisk utbildningstidskrift (KRUT) 133/134, 16-23. https://doi.org/10.1111/j.1755-2567.1957.tb00271.x

Dahlen, M. (2020). En liten bok om lycka. Stockholm: Volante.

Dahlgren, L-O. (1990). Undervisningen och det meningsfulla lärandet. Universitet i Linköping: Skapande Vetande.

Eklund, S. (2020). Livets små njutningar: Somna med hund och 46 andra upplevelser som gör livet värt att leva. Stockholm: Brombergs.

Flygt, T. (2001). Underdog. Stockholm: Norstedts.

Hansson, J-H., \& Svensson, T. (1998). Normalitetsproduktion: Teknik eller politik? I S. Sjöström (red.), Nya kulturer i psykiatrin. Lund: Studentlitteratur.

Huss, M., Manns, U., \& Ruin, H. (2016). Tid, minne, representation. Om historiemedvetandets förvandling. (RJ:S Skriftserie 13). Makadam förlag \& Riksbankens Jubileumsfond: Göteborg \&Stockholm.

Larsson, S. (2009). A pluralist view of generalization in qualitative studies. International Journal of Research \& Method in Education, 32(1), 25-38. https://doi.org/10.1080/17437270902759931

Johansson, M. (2008). Slöjdämnet - urgammalt, modernt och coolt. Kritisk utbildningstidskrift (KRUT) 133/134, 5-13.

Marjanen, P., Lindfors, E., \& Ketola, S. (2018). School Craft in Memories of Three Generations. Techne serien - Forskning i Slöjdpedagogik och Slöjdvetenskap, 25(1), 116.

Nordenstam, T. (2005). Exemplets makt. Dialoger, 69-70.

Olsén, R. (2003). Å se sider ved egen yrkespraxis. I E. Erson \& L. Öberg (red.), Erfarenhetens rum och vägar. 24 texter om kunskap och arbete. Botkyrka. Mångkulturellt centrum.

Samuelsson, M., Samuelsson, J., \& Kåreklint, L. (2014). Berättelser om goda lärare förs vidare. Venue, 2, 1-5. https://doi.org/10.3384/venue.2001-788X.1437

Tomasello, M. (2011). Därför samarbetar vi. Göteborg: Daidalos.

Tranströmer, T. (1993). Minnena ser dig. Stockholm: Albert Bonniers förlag.

Marcus Samuelsson är legitimerad lärare i slöjd, biträdande professor i pedagogik och forskningsledare för forskargruppen FoDiL - forskning om didaktiskt ledarskap vid Linköpings universitet. Hans forskningsintressen handlar förutom om slöjd och erfarenheter eller upplevelser av att vara med i en slöjdverksamhet också om ledarskap, lärares ledarskap, motstånd såväl som om simuleringar och simuleringsundervisning som stöd för utveckling och lärande. 
Slöjdkunnande i förändring - Eleverna och slöjden 